\title{
EFFECT OF IRON AND VITAMIN B 12 INJECTION ON BODY MEASUREMENTS AND SOME BLOOD CHARACTERISTICS OF AWASSI LAMBS
}

Wissam. J. Mohammed Ali Wassem.K.Ahmad Mohammed. S. Abrahem Animal Production, College of Agriculture and Forestry, University of Mosul.

Email: Wassem.khalid1986@Gmail.com

\begin{abstract}
The current study was conducted on 15 Awassi lambs with an average weight $11.24 \pm 0.06 \mathrm{~kg}$ ( 1 month aged), Lambs were randomly divided into three groups, (5 lambs/group) $1^{\text {st }}$ group: control, $2^{\text {nd }}$ group injected subcutaneously once every ten days with Iron and Vitamin $\mathrm{B}_{12}(4.54 \mathrm{mg} / \mathrm{kg}$ body weight and $4.54 \mu \mathrm{g} / \mathrm{kg}$ body weight ) $3^{\text {rd }}$ group: lambs were injected subcutaneously with Iron and vitamin $B_{12}$ $(9.09 \mathrm{mg} / \mathrm{kg}$ body weight and $9.09 \mu \mathrm{g} / \mathrm{kg}$ body weight ) respectively. Results showed a significant increase $(\mathrm{P} \leq 0.05)$ in final weight, total gain, daily gain, body length, chest girth, fore thickness, lymphocyte $\%$ and monocyte $\%$ in treated groups with Iron and vitamin $\mathrm{B}_{12}$ compared with control group. Also results shows a significant increase $(\mathrm{P} \leq 0.05)$ in $2^{\text {nd }}$ group lambs in fore height, rear height and rear thick. While there are a significant decrease in treated groups in neutrophils $\%$ and stress indices. In conclusion, iron and vitamin $\mathrm{B}_{12}$ injection improved body measurements and weights body immunity in Awassi lambs.
\end{abstract}

Key words: Awassi Lambs, Measurements body, immunity, Iron, Vitamin $B_{12}$

Received: 18 / 8 / 2019, Accepted: 23 / 9 / 2019

\section{INTRODUCTION}

The importance of iron is shown in it's vital role in a numbers of body functions such as oxygen transport, energy production (ATP), DNA synthesis and its important role in protecting cells from oxidation processes (Cann and Ames, 2007); (Clare, et al., 2007; Ronald, 2009 and Youssef, 2012) as well as the important course of growth (Drakesmith and prentice, 2008). Some clinical signs occur of iron in animals such as low growth rates and underutilized foods (Underwood and Suttle, 2001). Iron deficiency resulted reduce in immune system effectiveness towards pathogens (Hemminki, et al., 1991), also leads to a decrease in the functions of white blood cells and the production of antibodies (Scott, et al., 1975). Vitamin $B_{12}$ is the basis for the metabolism of all types of animals, and it is essential to strengthen ewes during pregnancy and lactation as well as developing birth to stimulate the immune system (Girard et al.,1996 and Papadopoulou et al.,(2013). Vitamin $B_{12}$ deficiency leads to reduced growth rates and birth weight as well as reduces the immune system functions of the animal. This study was designed to determine the effect of subcutaneous injections of iron and vitamin $B_{12}$ on The weight and Measurements immune performance of the Awassi lambs. 


\section{MATERIALS AND METHODS}

The study was carried out in a field of sheep breeder in Baibokhet area $(8 \mathrm{~km}$ north of Mosul), 15 Awassi lambs were randomly assigned to three groups (5 lambs / group) with average weight $11.24 \pm 0.06 \mathrm{~kg} .1^{\text {st }}$ group : control, the $2^{\text {nd }}$ group injected S.C with iron and vitamin $B_{12}(4.54 \mathrm{mg} / \mathrm{kg}$ body weight and $4.54 \mu \mathrm{g} / \mathrm{kg}$ body weight). The $3^{\text {rd }}$ group injected S.C with an Iron and Vitamin $B_{12}(9.09 \mathrm{mg} / \mathrm{kg}$ body weight and $9.09 \mu \mathrm{g} / \mathrm{kg}$ body weight), respectively once every ten days for 3 months. Blood samples were taken from the jugular vein $(3 \mathrm{ml} /$ animal $)$, replaced in container tubes contained (EDTA) ( Al-draghi et al., 2008). The following measurements were taken during the study :

1- Measurements of lambs body: Hands measuring tape and Caliper were used for measurements of , body length, chest girth, Fore height, rear height, fore thickness and chest depth $(\mathrm{cm})$. These measurements were taken after the stability of the animal and standing in normal position.

2- White blood cells count: were determined by the use of method of (Lewis and Bain, 2001).

3- Differential leucocyte count : calculated on blood smears dyed with Leishman stain (Thrall et al., 2004). Stress indices was calculated as : neutrophil/lymphocyte.

4- Weights: Lambs were weighed before the start of the study Then weighted monthly

Data were statistically analyzed using CRD Design and Duncan (1955) multiple range test used to test the differences between means by using Anonymous, (2005) statistical model was the following :

$\mathbf{Y}_{\mathrm{ijk}}=\boldsymbol{\mu}+\mathbf{T}_{\mathrm{i}}+\mathbf{e}_{\mathbf{i j k}}$

$\mu=$ the overall mean

$\mathrm{T}_{\mathrm{i}}=$ The effect of the treatment.

$\mathrm{e}_{\mathrm{ijk}}=$ the random error effect.

\section{RESULTS AND DISCUSSION}

Table (1) showed no significant differences $(\mathrm{P} \leq 0.05)$ in initial weight of lambs, a significant increase $(\mathrm{P} \leq 0.05)$ in treated groups with iron and vitamin $\mathrm{B}_{12}$ as compared with control group in final body weight and total and daily weights gain. These result are in agreement with the study of Vatn and feramstad, (2000); vellema et al., (1997); lind and blum, (1994) and Ali, (1992). The increase in body weight is due to the important role of iron and vitamin $\mathrm{B}_{12}$ in growth that is reflected on body weight (papadopoubuet al., 2013, and Drakesmith and prentice, 2008).

Table (2) shows a significant increase $(\mathrm{P} \leq 0.05)$ in treated groups ( iron and vitamin $\mathrm{B}_{12}$ ) compared with control group, in body length, chest girth, fore thick, chest depth, $2^{\text {nd }}$ group were Increased significantly $(\mathrm{P} \leq 0.05)$ in fore height, rear height and rear thick. The increase in the rate of body measurements in treated groups may be due to a positive correlation between the increase in body weight with measurements and body dimensions (Naziroglu, et al., 1997). 
Table (1) : Mean \pm S.E Effect of Iron and Vitamin $B_{12}$ injection on body weight of Awassi lambs.

\begin{tabular}{|c|c|c|c|c|}
\hline groups Characteristics & $\begin{array}{c}\text { Initial } \\
\text { B.W(kg) }\end{array}$ & $\begin{array}{l}\text { Final B.W } \\
\quad(\mathrm{kg})\end{array}$ & $\begin{array}{c}\text { Total B.W } \\
\text { gain }(\mathrm{kg})\end{array}$ & $\begin{array}{c}\text { Daily B.W } \\
\text { gain }(\mathrm{kg})\end{array}$ \\
\hline Control & $\begin{array}{l}11.26 \mathrm{a} \\
\pm 0.07\end{array}$ & $\begin{array}{c}23.66 \mathrm{~b} \\
\pm 0.08\end{array}$ & $\begin{array}{l}12.40 \mathrm{~b} \\
\pm 0.05\end{array}$ & $\begin{array}{l}0.137 \mathrm{~b} \\
\pm 0.01\end{array}$ \\
\hline $\begin{array}{c}\text { Iron } 4.54 \mathrm{mg}+ \\
\text { vitamin } \mathrm{B}_{12} 4.54 \mu \mathrm{g} / \\
\mathrm{kg} \text { body weight }\end{array}$ & $\begin{array}{l}11.06 \mathrm{a} \\
\pm 0.09\end{array}$ & $\begin{array}{l}25.63 \mathrm{a} \\
\pm 0.07\end{array}$ & $\begin{array}{l}14.60 \mathrm{a} \\
\pm 0.06\end{array}$ & $\begin{array}{l}0.162 \mathrm{a} \\
\pm 0.03\end{array}$ \\
\hline $\begin{array}{c}\text { Iron } 9.09 \mathrm{mg}+ \\
\text { vitamin } \mathrm{B}_{12} 9.09 \mu \mathrm{g} / \\
\mathrm{kg} \text { body weight }\end{array}$ & $\begin{array}{l}11.39 \mathrm{a} \\
\pm 0.02\end{array}$ & $\begin{array}{l}25.83 \mathrm{a} \\
\pm 0.05\end{array}$ & $\begin{array}{l}14.44 \mathrm{a} \\
\pm 0.04\end{array}$ & $\begin{array}{l}0.160 \mathrm{a} \\
\pm 0.02\end{array}$ \\
\hline
\end{tabular}

*Means in each column with different letters are differs significantly at $(\mathrm{P} \leq 0.05)$.

Table (2) : Mean \pm S.E Effect of Iron and Vitamin $B_{12}$ injection on some body dimensions $(\mathrm{cm})$ of Awassi lambs.

\begin{tabular}{|c|l|l|l|l|l|l|l|}
\hline groups & $\begin{array}{c}\text { Body } \\
\text { length } \\
(\mathrm{cm})\end{array}$ & $\begin{array}{l}\text { Chest } \\
\text { girth } \\
(\mathrm{cm})\end{array}$ & $\begin{array}{c}\text { Fore } \\
\text { height } \\
(\mathrm{cm})\end{array}$ & $\begin{array}{c}\text { Rear } \\
\text { height } \\
(\mathrm{cm})\end{array}$ & $\begin{array}{l}\text { Fore } \\
\text { thick } \\
(\mathrm{cm})\end{array}$ & $\begin{array}{c}\text { Rear } \\
\text { thick } \\
(\mathrm{cm})\end{array}$ & $\begin{array}{c}\text { Chest } \\
\text { depth } \\
(\mathrm{cm})\end{array}$ \\
\hline control & $\begin{array}{l}43.00 \mathrm{~b} \\
\pm 0.04\end{array}$ & $\begin{array}{l}65.00 \mathrm{~b} \\
\pm 0.09\end{array}$ & $\begin{array}{l}53.00 \mathrm{~b} \\
\pm 0.04 .\end{array}$ & $\begin{array}{l}56.50 \mathrm{~b} \\
\pm 0.06\end{array}$ & $\begin{array}{l}14.00 \mathrm{~b} \\
\pm 0.08\end{array}$ & $\begin{array}{l}15.00 \mathrm{~b} \\
\pm 0.02\end{array}$ & $\begin{array}{l}26.50 \mathrm{~b} \\
\pm 0.05\end{array}$ \\
\hline $\begin{array}{c}\text { Iron } 4.54 \mathrm{mg}+ \\
\text { vitamin } \mathrm{B}_{12} 4.54 \\
\mu \mathrm{\mu g} / \mathrm{kg} \text { body } \\
\text { weight }\end{array}$ & $\begin{array}{l}50.50 \mathrm{a} \\
\pm 0.05\end{array}$ & $\begin{array}{l}72.50 \mathrm{a} \\
\pm 0.04\end{array}$ & $\begin{array}{l}64.50 \mathrm{a} \\
\pm 0.05\end{array}$ & $\begin{array}{l}64.00 \mathrm{a} \\
\pm 0.04\end{array}$ & $\begin{array}{l}18.50 \mathrm{a} \\
\pm 0.05\end{array}$ & $\begin{array}{l}19.00 \mathrm{a} \\
\pm 0.04\end{array}$ & $\begin{array}{l}27.50 \mathrm{~b} \\
\pm 0.04\end{array}$ \\
\hline $\begin{array}{c}\text { Iron 9.09 mg }+ \\
\text { vitamin } \mathrm{B}_{12} 9.09 \\
\mu \mathrm{g} / \mathrm{kg} \text { body } \\
\text { weight }\end{array}$ & $\begin{array}{l}53.50 \mathrm{a} \\
\pm 0.02\end{array}$ & $\begin{array}{l}71.00 \mathrm{a} \\
\pm 0.07\end{array}$ & $\begin{array}{l}58.50 \mathrm{a} \\
\pm 0.08\end{array}$ & $\begin{array}{l}61.00 \mathrm{a} \\
\pm 0.09\end{array}$ & $\begin{array}{l}17.00 \mathrm{a} \\
\pm 0.06\end{array}$ & $\begin{array}{l}16.29 \mathrm{ab} \\
\pm 0.06\end{array}$ & $\begin{array}{l}30.50 \mathrm{a} \\
\pm 0.09\end{array}$ \\
\hline
\end{tabular}

*Means in each column with different letters are differs significantly at $(\mathrm{P} \leq 0.05)$.

Table (3) showed there is no significant difference between the treated groups and control in white blood cells, basophils $\%$, lymphocytes $\%$ and monocytes $\%$, also a significant decrease $(\mathrm{P} \leq 0.05)$ in neutrophils $\%$ and stress indices in favor of the in treated. $3^{\text {rd }}$ group were significant increase $(\mathrm{P} \leq 0.05)$ compared with control group in eosinophil\%. This increase in white blood cells of the treatment groups compared to the control group may be due to improvements in the immune function of the body (Meydani et al., 1990). Changes in the differential number of white blood cells, which were significantly higher in lymphocytes of the treated groups, were associated with a significant reduction of the neutrophil cells compared to the control group and the effect on the stress indices, that were represented on the improvement of animals immune status and decrease stress effects (khrofa, 2013). 
This can be attributed to the role of iron and vitamin $\mathrm{B}_{12}$ which improved body immune system (Yusuf, 2012 and Papadopoulou et al., 2013).

Table (3): Mean \pm S.E Effect of Iron and Vitamin $B_{12}$ injection on white blood cells count and differential leucocyte count of Awassi lambs.

\begin{tabular}{|c|c|c|c|c|c|c|c|}
\hline $\begin{array}{c}\text { Characteristics } \\
\text { groups }\end{array}$ & $\begin{array}{c}\text { WBC x } \\
\left(\mathrm{mm}^{3}\right) 10^{3}\end{array}$ & $\begin{array}{c}\text { Lympho } \\
\text { cyte\% }\end{array}$ & $\begin{array}{c}\text { Neutro } \\
\text { phil\% }\end{array}$ & $\begin{array}{c}\text { Acido } \\
\text { phil\% }\end{array}$ & $\begin{array}{c}\text { Monoc } \\
\text { yte\% }\end{array}$ & $\begin{array}{c}\text { Basophil } \\
\text { s\% }\end{array}$ & $\begin{array}{c}\text { Stress } \\
\text { indices } \\
\mathrm{N} / \mathrm{L}\end{array}$ \\
\hline control & $\begin{array}{c}9.66 \mathrm{a} \\
\pm 0.15\end{array}$ & $\begin{array}{c}47.75 \mathrm{~b} \\
\pm 0.10\end{array}$ & $\begin{array}{c}48.75 \mathrm{a} \\
\pm 0.03\end{array}$ & $\begin{array}{c}1.25 \mathrm{~b} \\
\pm 0.25\end{array}$ & $\begin{array}{c}1.75 \mathrm{~b} \\
\pm 0.25\end{array}$ & $\begin{array}{c}1.00 \mathrm{a} \\
\pm 0.00\end{array}$ & $\begin{array}{c}1.02 \mathrm{a} \\
\pm 0.04\end{array}$ \\
\hline $\begin{array}{c}\text { Iron } 4.54 \mathrm{mg}+ \\
\text { vitamin } \mathrm{B}_{12} 4.54\end{array}$ & $11.40 \mathrm{a}$ & $56.25 \mathrm{a}$ & $39.00 \mathrm{~b}$ & $2.00 \mathrm{ab}$ & $2.25 \mathrm{a}$ & $1.00 \mathrm{a}$ & $0.68 \mathrm{~b}$ \\
$\mu \mathrm{g} / \mathrm{kg}$ body & \pm 0.17 & \pm 0.47 & \pm 0.07 & \pm 0.28 & \pm 0.47 & \pm 0.00 & \pm 0.01 \\
weight & & & & & & & \\
\hline $\begin{array}{c}\text { Iron 9.09 mg }+ \\
\text { vitamin } \mathrm{B}_{12} 9.09\end{array}$ & $10.25 \mathrm{a}$ & $53.75 \mathrm{a}$ & $40.50 \mathrm{~b}$ & $2.50 \mathrm{a}$ & $2.75 \mathrm{a}$ & $1.00 \mathrm{a}$ & $0.72 \mathrm{~b}$ \\
$\mu \mathrm{mg} / \mathrm{kg}$ body & \pm 0.16 & \pm 0.62 & \pm 0.08 & \pm 0.25 & \pm 0.25 & \pm 0.00 & \pm 0.02 \\
weight & & & & & & & \\
\hline
\end{tabular}

*Means in each column with different letters are differs significantly at $(\mathrm{P} \leq 0.05)$.

$$
\begin{aligned}
& \text { تأثير حقن الحديد و فيتامين B12 في قياسات الجسم وبعض صفات الدم للحملان العواسية }
\end{aligned}
$$

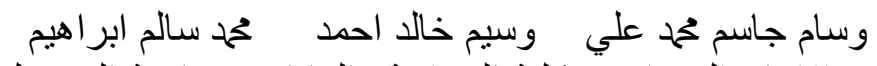

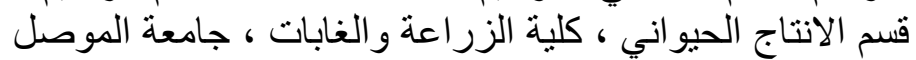

$$
\begin{aligned}
& \text { Email: Wassem.khalid1986@Gmail.com }
\end{aligned}
$$

\section{الخلاصة}

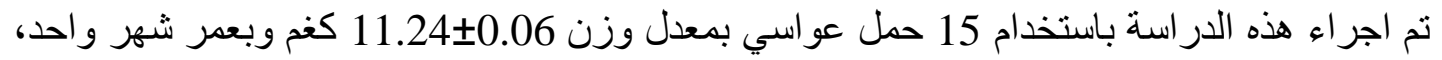

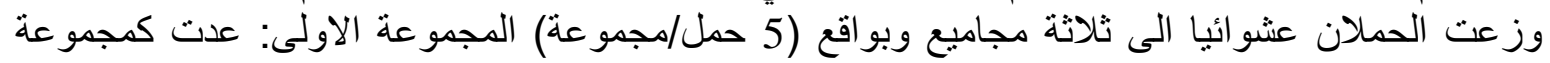

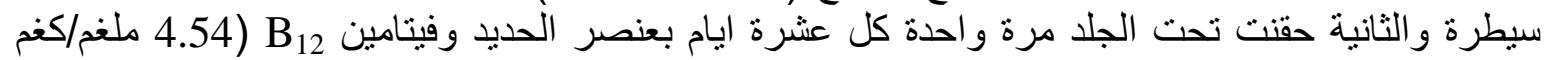

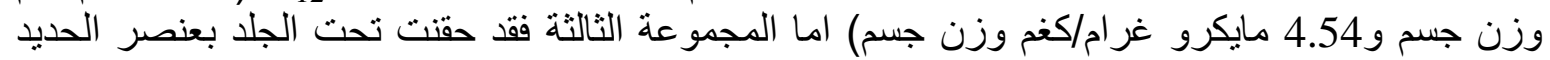

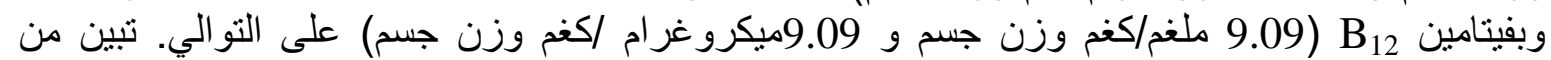

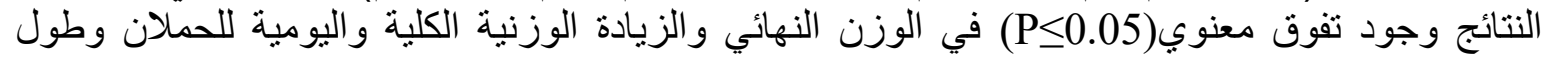

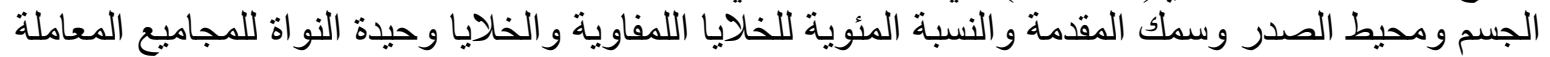

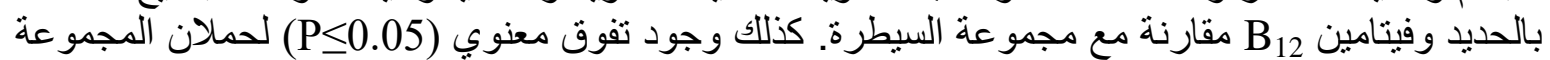

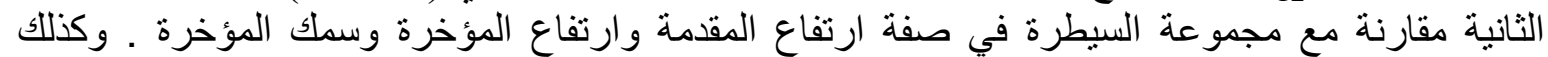

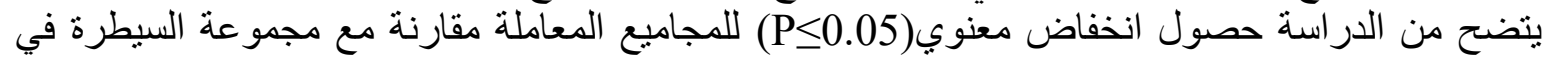

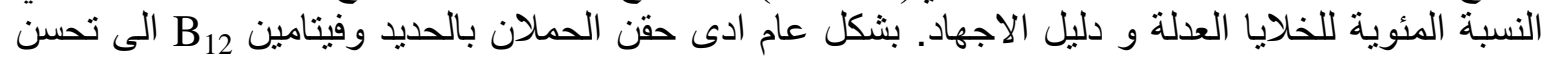

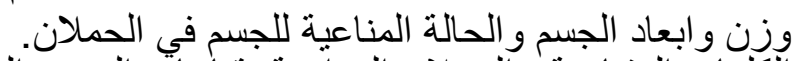

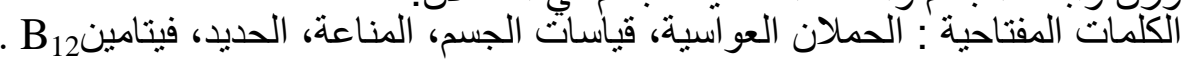

تاريخ استلام البحث : 18 / 8 / 2019 وقبوله : 23 / 9 /2019

\section{REFERENCES}

Abdi, P. S.(2006).Effect of Vitamin A and E in Some Phylogenetic and Reproductive Characteristics of Intestinal Sheep Plaques. Master Thesis. Faculty of Agriculture and Forestry. University of Mosul. 
Al-draghi, H. J., W. K Alhyani and A. S Alhusieni.(2008). "Physiology of Bird's Blood", College of Agriculture, University of Baghdad.

Ali, M. H.(1992).Comparative Study of Hematinic in Goat .M Sc. Thesis, Bangladesh Agricultural university of Bangladesh.

Anonymous, SAS.(2005).Statistical Analysis System .User's guide for personal computer release 8 . SAS Institute Inc. ,Cary, NC, U.S.A.

Cann, J and P.N Ames.(2007).An overdrew of evidence for causal relation between iron deficiency during development and deficits in cognitive or behavioral function. Am. J. Clin. Nutr.985(4):931-945.

Clare, H., K .Mary, A. Dennis., B. Ian, R. Paula, B. Maxime, O.C. Jacqueline, C. Charles, J. Strain and W. Julie. (2007).Effect of zinc supplementation on the immune status of healthy older in dividuals aged 55-70. Years: The Zenith study .J. of Gerontology: Biological sciences.62A(6):598-608.

Drakesmith, $\mathrm{H}$ and A. prentice, (2008). Viral in fiction and iron metabolism. Nature Reviews Microbidogy,6(7):541-552.

Duncan, D. B.(1955). Multiple range and Multiple F test. Biometrics.11: 1- 42

Gabryszuk, M. and J. Klewiec.(2002). Effect of injecting 2-and3-year-old ewes with selenium and selenium - vitamin $\mathrm{E}$ on reproduction and rearing of lambs. Small Rumen. Res..(43):127-132.

Girard, C.L., F. Castonguay, F. Fahmy and J.J. Matte.(1996).Serum and milk foliate during the first two gestations and lactation in Romanovs, Finn sheep, and Suffolk ewes. J. Anim. Sci., 74:1711-1715.

Hemminki, .L., U. Rimpela, A. Yla-Outinen. ( 1991).Iron prophylaxis during pregnancy and infection .J. vit. nutr. Res, 1:370-371.

Khrofa, W. K. A.(2013). Effect of Vitamin E and Selenium on Some Physiological Characters and Milk Production and Constituents of Meriz Goats. M.Sc. thesis, College of Agriculture, University of Mosul.

Lewis, M.L and B. J. Bain.(2001). Dacia and Lewis practical Hematology. Harcount publishers limited. $9^{\text {th }}$ edn.p320.

Lind, F and J.W. Blum, (1994).Growth performance hematological traits ,meat variables and effects of treadmill and transport stress in veal calves supplied different amounts of iron. J. Vet. Med. Series A.,41:333-42.

Meydani, S. N., Barklund, P.M and Liu,S.M.;Miller,R.A.,Cannon, J.G. Morrow,F.D.Rocklin, R. and J.B Blumberg.(1990).vitamin E supplementation enhances cell- medicated immunity in healthy elderly subjects. AM. J.Clin.Nutr.,52(3):557-563.

Naziroglu, M., Aksakal, L. Cay, M, and Celik, M.S.(1997).Effect of vitamin E and selenium on some rumen parameters in lambs.,Acta.vet.Hung., 45:447-456.

Papadopoulou,E.,N.Stratakis,T.Roumeliotake,K.sarri,D.Fmerlo,M.Kogevinas,L.Cha tzi(2013).The effect of high doses of folic acid and iron supplementation in early-to-mid pregnancy on prematurity and fetal growth retardation: the mother-child cohort study in Crete, Greece (Rhea Study).Eur.J.Nutr.,52:327-336.

Ronald, W.(2009).Hand book of nutrition in the Aged. $4^{\text {th }}$ Edition. Taylor and franc is group-New york. 
Scott, P.H., H.M Gergerand C. Kenwart.(1975).Effect of gestational age and intra uterine nutrition on plasma transferrin and iron in the newborn. Arch. of Dis. of child., 50:796-798.

Thrall, M., Baker, D.C. ;Campbell, T.W., AND Weiser, G.G.(2004).Laboratory technology for veterinary medicine in :Veterinary Hematology and clinical chemistry. $\left(1^{\text {st }}\right.$ ed). Lipping of Wilkins 351 west camdlen street Baltimore Mar gland 21201.USA.9-14.

Underwood, E.J and N.F Suttle.(2001).Iron in the mineral nutrition of livestock $.3^{\text {rd }}$ .Biddies Ltd. London,pp.375-395.

Vatn, S and T. Framstad .(2000).Anemia in housed lambs effects of oral iron on clinical pathology and performance. Act Vet. Scandinavia, 41:273-81.

Vellema, P.L., H.W. Barkema and Y.H. Schukken.(1997).Effect of cobalt supplementation on serum vitamin $B_{12}$ levels weight gain and survival rate in lambs, grazing cobalt deficient pastures, Vet . Quarterly, 19:1-5.

Youssef, M. K. (2012). Directory of Health Nutrition for Cancer, South Egypt Institute of Oncology, Assiut University. 